\title{
Ecohydrological Implications of Drought for Forests in the United States
}

Running Head: Ecohydrologic implications of drought

James M. Vose ${ }^{1,2}$, Chelcy Ford Miniat ${ }^{3}$, Charles H. Luce ${ }^{4}$, Heidi Asbjornsen ${ }^{5}$, Peter V.

Caldwell $^{3}$, John L. Campbell ${ }^{6}$, Gordon E. Grant ${ }^{7}$, Daniel J. Isaak ${ }^{8}$, Steven P. Loheide II ${ }^{9}$, Ge Sun $^{10}$

${ }^{1}$ J.M. Vose, U.S. Department of Agriculture, Forest Service, Southern Research Station, Center for Integrated Forest Science, Department of Forestry and Environmental Resources, Raleigh, NC 27695; ${ }^{3}$ C.F. Miniat, U.S. Department of Agriculture, Forest Service, Southern Research Station, Center for Forest Watershed Research, Coweeta Hydrologic Laboratory, Otto, NC 28763; ${ }^{4}$ C.H. Luce, U.S. Department of Agriculture, Forest Service, Rocky Mountain Research Station, Boise, ID, 83702; ${ }^{5}$ H. Asbjornsen, Department of Natural Resources, University of New Hampshire, Durham, NH 03824; ${ }^{3}$ P. V. Caldwell, U.S. Department of Agriculture, Forest Service, Southern Research Station, Center for Forest Watershed Research, Coweeta Hydrologic Laboratory, Otto, NC 28763; ${ }^{6}$ J. L. Campbell, U.S. Department of Agriculture, Forest Service, Northern Research Station, Center for Research on Ecosystem Change, Durham, NH 03824; ${ }^{7} \mathbf{G}$. E. Grant, U.S. Department of Agriculture, Forest Service, Pacific Northwest Research Station, Ecological Process and Function Program, Forestry Science Laboratory, Corvallis, OR 97331;

${ }^{8}$ D. J. Issak, U.S. Department of Agriculture, Forest Service, Rocky Mountain Research Station, Boise, ID, 83702; ${ }^{9}$ S. P. Loheide II, Civil and Environmental Engineering, University of Wisconsin, Madison-Madison, WI 53706; ${ }^{10}$ G. Sun, U.S. Department of Agriculture, Forest Service, Southern Research Station, Eastern Forest Environmental Threat Assessment Center, Raleigh, NC 27695 
${ }^{2}$ corresponding author: jvose@fs.fed.us; ph. 919-506-0924

\begin{abstract}
The relationships among drought, surface water flow, and groundwater recharge are not straightforward for most forest ecosystems due to the strong role that vegetation plays in the forest water balance. Hydrologic responses to drought can be either mitigated or exacerbated by forest vegetation depending upon vegetation water use and how forest population dynamics respond to drought. Understanding how drought impacts ecosystems requires understanding how drought impacts ecohydrological processes. Because different species and functional groups vary in their ecophysiological traits that influence water use patterns, changes in species assemblages can alter hydrological processes from the stand to the watershed scales. Recent warming trends and more prolonged and frequent droughts have accelerated the spread and intensity of insect attacks in the western US that kill nearly all of the canopy trees within forest stands, changing the energy balance of the land surface and affecting many hydrologic processes. In contrast, some eastern forest tree species and size classes can tolerate drought better than others, suggesting the potential for drought-mediated shifts in both species composition and structure. Predicting how these changes will impact hydrologic processes at larger spatial and temporal scales presents a considerable challenge. The biogeochemical consequences of drought, such as changes in stream chemistry, are closely linked to vegetation dynamics and hydrologic responses. As with other natural disturbances, droughts are difficult to prepare for because they are unpredictable. However, there are management options that may be implemented to minimize the impacts of drought on water quantity and quality. Examples include reducing leaf
\end{abstract}


area by thinning and regenerating cut forests with species that consume less water, although a high level of uncertainty in both drought projections and anticipated responses suggests the need for monitoring and adaptive management.

Keywords: transpiration, streamflow, water balance, water quality, climate change, management options

\section{Introduction}

In simple terms, drought means less water-less water for plants and less water for streams and groundwater recharge relative to normal conditions. In some regions, annual or seasonal water deficits are common, and forest and stream ecosystems often adapt to these somewhat predictable disturbances through various physiological, morphological, and behavioral adaptations (Lytle and Poff, 2004; McDowell et al., 2008). In contrast, multiyear or severe water deficits (i.e., severe drought) are less predictable and may exceed the adaptive capacity of the ecosystem, resulting in substantial hydrological and stream biogeochemical responses (Lake, 2003). The relationships among drought, surface water flow, and groundwater recharge are not straightforward because forest ecosystems have a large capacity to regulate precipitation partitioning through the evapotranspiration process (Sun et al., 2011). There is a lack of understanding of the interactions of physical (e.g., topography, slope, aspect, soil characteristics) and biological factors (e.g., species composition, age, rooting depth, etc.) in forest ecosystems, especially under extreme climatic conditions (Vose et al., 2011). Projections of warmer temperatures and more extreme precipitation events (e.g., longer dry spells) across many areas 
of the US suggest that forests will experience more extreme drought conditions in the future (see Luce et al. 2016, this issue).

Hydrologic responses to drought can be either mitigated or exacerbated by forest vegetation depending upon vegetation water use and how drought affects forest population dynamics. In the most extreme cases, droughts and heat waves can trigger widespread tree mortality, as has been observed in forests in the western U.S. (Allen et al., 2010; Weed et al., 2013). There is evidence that forests across all biomes might be equally vulnerable to drought (Choat et al., 2012), with drought causing species-specific mortality in mesic eastern forests as well (Klos et al., 2009). Examining the interactions and feedbacks among drought, hydrological processes, and the structure and function of vegetation provides an ecohydrological context for evaluating the impacts of drought on water resources (Rodriguez-Iturbe, 2000; Breshears et al., 2005) as well as other ecosystem services (Sun et al., 2015a, 2015b).

Forests naturally grow where water is sufficient to support perennial woody vegetation, as forest evapotranspiration (ET) is typically much greater than other vegetation types (Frank and Inouye, 1994; Sun et al., 2011). Where precipitation $(P)$ inputs substantially exceed evapotranspiration $(E T)$ losses, surface water draining forest land is typically of high quality and supports many human uses (Binkley and Brown, 1993; Vose et al., 2011), as well as aquatic ecosystems and species (e.g., Rieman et al., 2003; Peterson et al., 2013). In addition to being important for providing high quality surface water supply, forests modulate the quantity and timing of streamflows by intercepting and transpiring precipitation (Sun et al., 2011), and influencing snow melt timing (Lundquist et al., 2013). Forests are also commonly important areas for groundwater recharge (Price, 2011) and flood mitigation (Beschta et al., 2000; Jones 
and Perkins, 2010). Because of the importance of forests for water and other ecosystem services (e.g., carbon sequestration), there is a critical need to understand drought impacts on hydrological processes in forest ecosystems (Sun et al., 2015a, 2015b).

In this review paper, we examine how differences in forest species composition and structure impact evapotranspiration, interpret these changes in the context of mitigating or exacerbating the impacts of drought on streamflow and groundwater recharge, and discuss the impacts of hydrologic drought on watershed processes and water quality. This review is a modified version of a comprehensive synthesis developed as a contribution to the sustained National Climate Assessment process (www.globalchange.gov/enagage/processproducts/sustained -assessment; Vose et al., 2016).

\section{Catchment Scale Responses to Drought}

At annual time steps, the water balance of a forested catchment can be described by: $Q=P-E T-\Delta S$,

where $Q$ represents streamflow, and is the balance of precipitation inputs $(P)$, after losses to evapotranspiration (ET, the sum of interception, transpiration and soil evaporation) and changes in storage $(\Delta S)$ (Figure 1). The assumption that changes in storage are zero under severe drought conditions may not be correct in some instances and may yield incorrect interpretations of the impacts of drought on $Q$ using P-ET approaches (Vose and Swank, 1994; Creutzfeldt et al., 2012). Regardless, $Q$ can change in response to drought directly through reductions in $P$ and indirectly via ET responses to changing evaporative energy and water availability; however, these responses are especially complex. For a particular watershed, drought effects on $Q$ can vary greatly in space and time depending on the timing of reduced precipitation inputs (growing 
season vs. non- growing season), the magnitude of precipitation deficit, and watershed characteristics (e.g., vegetation, watershed size and configuration, terrain features, soil depth and storage capacity, and hydrogeology). For example, on shorter time scales, ET can exceed $P$, particularly when water used in ET is derived from soil water stores or deeper groundwater stores, rather than recent or local $P$ (Loheide et al., 2005; Lubczynski and Gurwin, 2005).

The catchment water balance equation can be also used to evaluate differential sensitivities of ET and $Q$ to drought. In general, sensitivity depends most strongly on temporal and spatial storage in soil and groundwater pools, as well as snowpack in snow dominated ecosystems. For example, in places with deep soils and hence greater soil water storage, there may be an apparent reduced sensitivity of $E T$ and $Q$ to reduced precipitation (Ohnuki et al., 2008; Boggs et al., 2013) that may help enhance resilience to drought (Taylor et al., 2013). In contrast, steep, coarse and shallow soils that cannot retain water may represent systems with high $E T$ and $Q$ sensitivity to reduced precipitation. If accessible by trees roots, soil stores are more vulnerable to $E T$, so they deplete more rapidly, and approach a state of near zero discharge sooner (Fan and Miguez-Macho, 2011).

The sensitivity of low $Q$ to drought in forest ecosystems with deep or substantial groundwater storage can be thought of in two ways (Tague and Grant, 2009). In terms of absolute $Q$, they are more sensitive than systems with little storage because they generally sustain greater baseflow than systems with shallow and tight bedrock, and even a small fractional decline in low $Q$ can be a large number. In contrast, places with little baseflow cannot decline far in absolute terms, simply because there is already so little runoff. However, when described as a percent change due to either drought duration or precipitation recharge, the systems with greater groundwater storage are less sensitive. This differs from sensitivity to variations in the soil store, 
as we defined it, because water stored in soils (generally places where roots are more abundant) is vulnerable to evapotranspiration, but deep groundwater is not.

Streamflow from forests where the snowpack comprises a large proportion of annual $P$ is more sensitive to precipitation declines. When the annual precipitation is delivered as meltwater in one relatively large pulse, runoff generation is more efficient, and variations in potential ET have little effect on the total annual runoff, which is essentially dependent on how much snow accumulates and then melts. Similarly if most of the $P$ falls in the cold season, it is less vulnerable to evaporation, and is converted more efficiently to runoff. In such cases, ET may vary little as a function of precipitation, but variations in $\mathrm{P}$ will be transmitted to runoff reliably on an annual scale (Wolock and McCabe, 1999; Berghuijs et al., 2014), similar to more humid locations (Milly and Dunne, 2002) and locations with greater seasonality in $P$ (Wolock and McCabe, 1999). High degrees of snow heterogeneity caused by drifting or large elevation ranges in a basin provide substantial buffering of $Q$ variation through the year because deep drifts and high elevation snowpacks do not melt until late in the summer (Luce et al., 1998). Snowpack meltwater is slowly released during warmer periods in these systems, making them less vulnerable to variations in summertime precipitation, but it makes them more dependent on winter precipitation variations because of the long duration of snow storage in deep drifts. Buffering from snow heterogeneity is probably most pronounced in the high mountains of the western U.S. (e.g., Clark et al., 2011), and in these environments snow accumulation and residence times are less affected by warming than precipitation (Luce et al., 2014). In summary, the relationship between $P$ and $Q$ in areas where the snowfall fraction is high has the following characteristics: (1) inter-annual variations in $Q$ are dominated by inter-annual variations in $P$ (as opposed to variation in potential ET), (2) the $Q / P$ (the runoff ratio) is higher when the snowfall 
fraction is high, (3) the sensitivity of $Q$ to $P$ is enhanced when snowfall fraction is high, and (4) deep snow drifts buffer summer runoff in basins but make it more dependent on winter $P$.

Reduced $P$ not only affects $Q$ through the amount of water available, but also through its timing. For example, in western U.S. snowpack-dominated areas, a low snowfall winter creates a shallower snowpack that takes less time to melt; and can create an expectation for lower flows in late summer (Cayan et al., 2001; Westerling et al., 2006; Tague and Grant, 2009). While low elevation snowpacks are more sensitive to temperature in determining the melt timing (Mote, 2006), the effect of $P$ variability on center of timing of outflow can be quite pronounced from high elevation basins (Luce and Holden, 2009). The synoptic weather patterns giving rise to prolonged drought can also shape the nature of $P$ events making the relationship between hydrologic drought and meteorological drought dynamic (Potter and Chiew, 2011). If limited ET occurs due to dry land surface conditions, convective storms may produce less intense $P$ and less $P$ during a given storm. The reduction in $P$ may result in a greater proportion being intercepted by canopies or held in soil, reducing runoff. Water added to wet soils or vegetation is more likely to contribute to recharge compared to periodic wetting of a relatively dry soil or canopy. Higher interception maximizes the potential for recirculation of water between land and atmosphere; but exacerbates $Q$ responses during prolonged dry periods.

\subsection{Vegetation Dynamics, Streamflow and Drought}

Catchment scale responses to drought are heavily influence by vegetation, as vegetation exerts significant control on several hydrologic fluxes: evaporation, transpiration, canopy interception, forest floor interception, infiltration, overland flow, groundwater recharge, and

streamflow. In particular, transpiration can represent up to $\sim 70 \%$ of ET (Schlesinger and 
Jasechko, 2014) and ET can represent $>100 \%$ of $P$ (Sanford and Selnick, 2013). Data on streamflow responses across the range of vegetation-drought-climate in the U.S. are limited; and most of what we do know about how changes in vegetation impact $Q$ comes from catchmentscale forest harvesting, thinning, and species conversion studies. Adams et al. (2012) discuss differences in expected hydrologic responses between drought related changes in forest cover versus harvesting; however, harvesting studies can provide a useful analog for postulating potential streamflow responses to drought. For example, extensive research in forest watershed ecosystems has shown that a reduction in forest cover from harvesting generally reduces stand transpiration and leads to an increase in streamflow (Bethlahmy, 1974; Bosch and Hewlett, 1982; Stednick, 1996; Zhang et al., 2001; Hadley et al., 2008). The response declines with vegetation regrowth and post-harvest streamflow may actually be lower than pre-harvest streamflow (Ford et al., 2011b). Streamflow responses are greatest in areas with higher precipitation and thinning studies suggest that reductions in canopy cover of less than $20 \%$ are difficult to detect at the catchment scale (Stednick, 1996). Vegetation responses to drought are more complex than what occurs after forest harvest, and the short and long-term effects on streamflow depend on a number of interacting factors. For example, droughts of short duration or frequency may only cause short-term physiological changes in existing vegetation such as stomatal closure or leaf area reduction. Post-drought recovery of streamflow would be expected to occur quickly as stomatal function recovers and leaves regrow. However, if drought frequency and duration increase, this can lead to large-scale changes in vegetation structure and species composition with long-term implications for streamflow. This process may occur abruptly and at large spatial scales, as in the case of mortality due to the interaction between drought and other stressors such as insects (Weed et al., 2013) and wildfire (Westerling et al., 2006). Or, this process may occur 
gradually, with weakened or drought in-tolerant trees selectively dying as a result as a direct consequence of moisture stress and cavitation.

Because data are limited, predictions of post-drought vegetation and streamflow responses across ecosystem types and climatic regimes are largely derived from synthesizing and extrapolating from a small number of studies or using simulation models. For example, Adams et al. (2012) provide a conceptual model for the ecohydrological consequences of large-scale forest die-off in coniferous forests in the western U.S., and suggest that where annual precipitation exceeds $500 \mathrm{~mm}$ or where water yield is driven primarily by snowmelt, drought-related tree mortality that exceeds $25 \%$ will result in increased $Q$. Forest cover-drought-streamflow relationships are more complex in semiarid regions (Wilcox and Thurow, 2006), where low rainfall, snowmelt dynamics, soils, and groundcover responses interact to determine impacts on $Q$ (Adams et al., 2012). For example, Guardiola-Claramonte et al. (2011) found that streamflow decreased following drought induced tree die-off in the southwestern U.S. due to an increase in evapotranspiration by understory vegetation. Extensive forest areas in the eastern U.S. have also experienced severe droughts in recent years causing tree mortality in many regions (Elliott and Swank, 1994; Klos et al., 2009). However, unlike western forests where large-scale drought related disturbances such as fire and insects often kill most of the overstory trees, some eastern forest tree species and size classes can tolerate drought better than others, suggesting the potential for drought-mediated shifts in both species composition and structure that favor drought tolerant and low water use species. For example, Klos et al., (2009) reported higher droughtrelated mortality in pine and mesophytic species groups (e.g., Liriodendron tulipifera, Acer spp, Betula, Fagus, Magnolia) than in oaks (Quercus spp). Tree-level sapflow data suggest wide variation in whole-tree daily water use among species groups (Wullschleger et al., 2001), and 
different sensitivities to water stress depending on xylem anatomy. A two- to three-fold difference among species (holding tree size constant) in mean daily water use can occur in these forests (Ford et al., 2011b), with oaks (e.g., Quercus rubra, Quercus prinus) generally having lower water use than more mesophytic species (e.g., Betula lenta, Liriodendron tulipifera) (Figs. 2-3). While oaks and hickories have a potential for high water use based on the diameter of their xylem conduits, field observations across the region (Fig. 4) suggest that these species operate under a fraction of this potential, thus lending support for their low observed water use (Fig. 3). Hence, if an increase in drought frequency and severity occurs in eastern hardwood forests, species-specific mortality may create more drought tolerant ecosystems with lower water use requirements. Using a modeling approach without considering the feedbacks of vegetation to hydrological drought, Sun et al. (2015a, 2015b) examined the 'top 5' droughts during the past 60 years in the U.S. and their impacts on watershed water yield and ecosystem productivity in US National Forests and Grasslands. They concluded that the $22 \%$ reduction in annual precipitation during the extreme drought years caused a reduction of water yield by $37 \%$ and ecosystem productivity by $9 \%$. By comparison, estimates for the 2002 drought, mostly occurred in western U.S., suggest a nation-wide reduction in water yield by $32 \%$ and productivity by $20 \%$.

In summary, the combination of observed responses from the individual tree to the watershed suggests that vegetation responses can result in contrasting impacts of drought on $Q$ and underscores the need for more research to understand the vegetation-drought-hydrology interactions and feedbacks that determine watershed scale effects on streamflow dynamics (Adams et al., 2012). Predicting how these changes will impact hydrologic processes at larger spatial scales presents a considerable challenge. At present, we do not know how these 
interactions and gradual changes will play out at larger landscapes and longer time scales, and our watershed models are inadequate to project large-scale responses.

\subsection{Groundwater Interactions with Drought}

When available to tree roots, groundwater may help vegetation avoid drought-induced effects (Ehleringer and Dawson, 1992). This strategy is well-known in groundwater-dependent ecosystems (Orellana et al., 2012) such as wetlands and riparian forests (Busch et al., 1992; Thorburn et al., 1992) but has also been recognized in upland systems (Dickson and Tomlinson, 1996; Miller et al., 2010), which can be referred to as groundwater-influenced ecosystems. Examples of groundwater dependent species include deep-rooted trees and shrubs such as cottonwood (Populus spp.), willow (Salix spp.), salt cedar (Tamarix spp.), greasewood (Adenostoma fasciculatum, Baccharis sarothroides, Glossopetalon spinescens, Larrea tridentate, and Sarcobatus vermiculatus.), and mesquite (Prosopis spp.). Phreatophytes can be obligate or facultative depending on whether they rely on perennial access or intermittent access to groundwater to avoid drought (Smith et al., 1998), with examples in the latter category including sagebrush (Artemesia spp.) and rabbitbrush (Chrysothamnus spp.) (Nichols, 1994). Phreatophytes (particularly those in arid regions) also employ a diverse array of other droughtavoidance and drought-tolerance strategies to survive dry periods including control of the magnitude and timing of leaf area, osmotic potential, leaf conductance, and maintenance of turgor at low leaf water potential (Nilsen et al., 1984).

The groundwater subsidies, as defined by Lowry and Loheide (2010), are provided to groundwater-dependent and groundwater-influenced ecosystems buffering them from adverse 
effects of drought. Maps depicting estimates of depth to groundwater (Fan et al., 2013) reveal that it is generally less than $5 \mathrm{~m}$ across vast regions of the U.S., which is within the critical range required to help offset the impacts of drought in forests and many other ecosystems (Maxwell and Kollet, 2008; Lowry and Loheide, 2010; Soylu et al., 2014). Even when groundwater is not regionally shallow, riparian and other areas may have shallow groundwater (Fan et al., 2013) resulting in local areas where groundwater is sufficient to buffer the effects of drought. Heterogeneity in groundwater depth across the landscape suggests the potential for management and protection strategies aimed at specific resources as the landscape becomes further fragmented into natural, urban, and agricultural systems (Jackson et al., 2009).

\subsection{Drought Impacts on Water Quality}

\subsubsection{Stream Nutrients \& Sediment}

The impacts of drought on water quality are closely linked to changes in vegetation and hydrology (Dahm et al., 2003). For example, Wurzburger \& Miniat (2014) found that tree species that have the ability to form $\mathrm{N}_{2}$-fixing nodules in their roots do so more under conditions of moderate drought, adding a new source of $\mathrm{N}$ into these systems that could be available for uptake and eventual leaching and stream export. Lutz et al., (2012) suggested that streamwater nitrate concentrations are affected by temporal trends in fine root production and mortality during drought. In the early stages of drought, root production may initially increase as trees attempt to access soil water over broader areas (Hendrick and Pregitzer, 1996), resulting in lower streamwater nitrate concentrations. Following drought, root mortality returns $\mathrm{N}$ to the system, resulting in higher stream nitrate. Secondary influences of drought on disturbances such as wildfire can also impact water chemistry and sediment (see Spencer et al., 2003; Smith et al., 
2011; Goode et al., 2012). Droughts can also have a concentrating effect on solutes in stream water due to the limited volume of water; however, the flux of solutes in stream water is generally lower during drought periods because less water is moving through the watershed. As streamflow declines, nutrients moving downstream are cycled more rapidly (Fisher et al., 1998). This more rapid uptake of solutes within streams can have a strong influence on their concentration.

Reduced streamflow velocity also enhances sediment and particulate organic matter deposition (Wood and Armitage, 1999; Acuña et al., 2007). Fine sediment deposition during drought has been shown to negatively affect stream organisms, such as macroinvertebrates and fish (Wood and Armitage, 1997; Hakala and Hartman, 2004; Kaller and Hartman, 2004; Kemp et al., 2011). In cases where streamflow ceases entirely, water becomes stagnant, and sediment, organic matter, and nutrients can accumulate in the pools that form. Severely reduced or eliminated flow, along with warmer temperatures, may promote algal growth (Caramujo et al., 2008) and reduce dissolved organic carbon (DOC) in streams (Everard, 1996). In most cases, the concentration and flux of DOC in stream water are low during drought years compared to normal or wetter years. The reduced export of DOC during droughts has been attributed to factors such as diminished flow and changing flow paths (Schindler et al., 1997; Eimers et al., 2008; Worrall and Burt, 2008; Porcal et al., 2009), decreased organic matter solubility during acidic episodes (Clark et al., 2005; Clark et al., 2006), and decreased production of DOC due to the inhibition of microbial processes associated with dry or acidic conditions during drought (Scott et al., 1998). Intermittent and ephemeral streams are particularly vulnerable to drought (Palmer et al. 2008), yet they serve critical roles for elemental cycling, connecting materials and energy exchange in watersheds (Lowe and Likens, 2005) and river networks, and providing unique 
habitat for plants (Katz and Moore, 2011) and other aquatic and terrestrial organisms (McDonough et al., 2011). Increasing the duration or frequency of drought will increase and alter periods of "no-flow" conditions and change hydrologic processes and aquatic habitats (Jaeger and Olden, 2012). These changing flow regimes are likely to have important implications for the timing and quantity of carbon, nutrient, and sediment exchanges with the perennial stream network, and alter habitat availability for fish and other aquatic organisms (Brooks, 2009). Species that utilize ephemeral and intermittent streams already have adaptations to survive dry periods; however, whether these traits will allow for survival under longer, more frequent, and more extreme droughts is uncertain (Robson et al., 2011), but of concern (Brooks, 2009; Acuna et al., 2014). For example, a prolonged drought had a much greater impact on fish and invertebrates in ephemeral and intermittent streams than in perennial streams in a Mediterraneanclimate (Beche et al., 2009).

Subsurface hydrologic flowpaths can also play a critical role in regulating the concentration of solutes in stream water. During droughts, groundwater continues to travel along deep, long flowpaths, whereas less water flows along shallow groundwater paths. As the water residence time increases along these deep flowpaths, the contact time between groundwater and bedrock lengthens, which results in higher concentrations of stream water solutes derived from geological weathering of bedrock. In contrast, during high flows, water tends to move more rapidly through upper soil horizons, resulting in higher concentrations of elements derived from organic matter, such as carbon and nitrogen (Swistock et al., 1989; Raymond and Saiers, 2010). Local lithology largely determines which elements will become more concentrated in stream water during drought. 
While it is typically difficult to determine when a drought begins, they are often punctuated by a more abrupt ending, at which point the biogeochemical impacts of droughts are most apparent. The first flush of water following drought has high concentrations of products that have accumulated in the soil (Burt et al., 2014). Aerobic processes in the vadose zone produce nitrate, sulfate and DOC that are transported to surface waters when a drought ends. The flushing of solutes can last for multiple storms, as saturated zones enlarge and hydrologic connections expand. Some solutes can have complex responses to drought, such as potassium, which has been shown to be influenced by changes in flow paths, sediment transport, and the chemical properties of stream water (Stott and Burt, 1997). Other solutes with more predictable responses to drought are those that are sensitive to oxidation-reduction reactions. For example, sulfate and nitrate tend to exhibit the strongest and most predictable responses to drought, especially in streams that drain wetland and riparian zones that are typically saturated.

\subsubsection{Stream temperature}

Stream water temperature is a critical water quality parameter that affects the chemical, biological, and ecological processes and functions of watersheds (Caissie, 2006), and influences the growth and distribution of aquatic organisms (Mohseni et al., 2003; Hester and Doyle, 2011). Droughts impact stream water temperatures primarily by decreasing stream discharge (flow volume and velocity) and increasing solar radiation (wildfires and limiting vegetation density), and to a lesser extent by changing atmospheric (precipitation, air temperature) and streambed factors (groundwater input). The low flows associated with droughts during warm periods cause stream temperatures to increase because thermal capacity is lower when flow volume decreases (Hockey, 1982; Webb, 1996; Webb et al., 2003) and slower water velocities allow streams to 
more strongly equilibrate to local climatic conditions (Meier et al., 2003; Isaak et al., 2012). Warmer waters hold less dissolved oxygen and drought conditions concentrate aquatic organisms in smaller habitat volumes. Droughts, therefore, can cause significant stress to fish and other aquatic organisms by increasing metabolic costs and the intensity of interspecific competitive interactions. For some highly-valued cold-water species like trout and salmon, temperatures often define the geographic extent of their habitat and drought conditions may temporarily constrain those habitats or even incur direct mortalities during extreme events. The lethal temperature limit for a cold-water trout species such as eastern brook trout (Salvelinus fontinalis) is approximately $25^{\circ} \mathrm{C}$ (Hokanson et al., 1977; Bjornn and Reiser, 1991); but, reduced growth begins to occur at temperatures well below this limit. Most aquatic organisms are ectothermic, so the limitations imposed by temperature and dissolved oxygen during droughts have broad implications for the growth and survival of individuals in many species (Bjornn and Reiser, 1991), including cold-water species.

\section{Challenges to Predicting the Impacts of Drought on Hydrological Processes}

Sensitivity analysis and empirical data suggest that the magnitude of hydrologic responses to droughts, due to climate warming or/and reduction in precipitation, vary tremendously under different climate and biophysical conditions (Ma et al., 2008; Lu et al., 2013). Predicting short-term responses to moderate and short duration droughts is generally more straightforward, especially if drought does not change above- and belowground forest structure. For example, at monthly or annual time scales over large areas, hydrologic models can capture much of the drought-related streamflow dynamics that occur simply as a direct result of reduced precipitation, or indirectly using an empirical soil moisture feedback (Sun et al., 2011; Caldwell 
et al., 2012). In addition to climatic dryness (potential ET/precipitation), terrain characteristics, land cover types, biomass, and soils all influence the potential impacts of droughts on watershed hydrology. This complexity poses considerable challenges for predicting the impacts of drought on hydrological processes. Adding leaf-level physiological responses (either mechanistically or empirically) and soil moisture dynamics can increase predictive ability (Hanson et al., 2004) although often these are "big-leaf" models that homogenize canopy variation and belowground responses.

Considerable uncertainty can result if models are unable to accurately account for aboveand belowground structural and functional vegetation responses that can occur after severe and/or long-term drought (Luo et al., 2008; Tague et al., 2013). Examples of long-term vegetation responses to drought include reduced leaf area index from abscission or mortality, altered root to shoot ratios (Joslin et al., 2007), differential species responses in mixed species stands (Ford et al., 2011a), and changing species composition (Klos et al., 2009; Anderegg et al., 2013). All of these factors drive or feed-back to evapotranspiration, ultimately influencing stand water balance and streamflow. One of the limitations of physically-based modeling approaches is that changes in vegetation structure (e.g., reduced leaf area, changing root distributions, etc.) and function (e.g., shifts to species with different mechanisms for regulation of water use) that may occur in response to severe drought are often not explicitly incorporated in the framework and require direct empirical investigation to understand (Powell et al., 2013). For example, short term droughts (e.g., < 1 year) may dry up depressional forested wetlands in the southeastern U.S., but hydrologic processes recover quickly and trees are rarely subject to water stress due to changes in soil water storage in wetlands (Lu et al., 2009; Sun et al., 2010). However, long-term droughts could alter wetland hydrology to an extent that causes permanent changes in plant community 
composition and fire regimes (De Steven and Toner, 2004) resulting in altered hydrologic processes at larger spatial scales. Furthermore, lumped parameter ecosystem models that intend to describe the effects of soil water on ecological processes such as carbon cycling, often treat soil water and nutrient movement in a rather simplified fashion. For example, lateral flow and topographic effects on soil water distribution on the landscape are usually not accounted for in ecosystem models (Govind et al., 2009) however, modeling approaches that account for subsurface hydrologic connectivity suggest strong spatial controls on ecosystem processes (Hwang et al., 2009; Emanuel et al., 2010).

More accurate predictions of the impacts of severe and longer-term drought (especially when vegetation changes occur) will require models that couple hydrologic and ecosystem processes in a dynamic context with appropriate feedbacks (Law et al., 2000). It is expected that ecosystem-specific models are needed to more fully determine hydrologic responses to extreme droughts. This is not a trivial expectation, as it requires models that couple leaf-level physiology, above- and belowground whole-tree responses, root dynamics and soil water access, stand level responses, and physical hydrology (Tague et al., 2013) and usually results in complex models that are difficult to parameterize and calibrate over large spatial scales.

\subsection{Management Options for Minimizing the Impacts of Drought on Water Quantity and Quality}

The concept of managing forests to augment annual streamflow is not new (Douglass, 1983); however, recent severe drought in many areas of the U.S. has increased awareness of the relationship among forest disturbance and management, drought, and streamflow (Ford et al., 
2011b; Jones et al., 2012). Since harvesting often increases annual water yield, it has been suggested that the effects of drought could be mitigated by cutting forests (e.g., McLaughlin et al., 2013). A major challenge in managing forests to enhance water supply is that a large proportion of the watershed has to be cut in order to increase annual runoff (Bosch and Hewlett, 1982), particularly in drier regions where additional water would be most valuable (Brown et al., 2005). For example, in the Boise River in southwestern Idaho, after $45 \%$ of the basin burned (about $1000 \mathrm{~km}^{2}$ ), there was about a 5\% increase in water yield (Luce et al., 2012). Consequently, the potential increases in streamflow through forest cutting are minimal due to limitations on the amount of land that can be harvested at any given time (Kattelmann et al., 1983). In warmer and moister regions, streamflow responses are often short-term due to rapid forest regrowth (especially in the eastern U.S., Swank et al., 2014), and the aggrading post-cut forest may actually have lower streamflow than the uncut forest (e.g., Ford et al., 2011b). A modeling study suggested that reducing leaf area by $50 \%$ may increase streamflow substantially in areas where precipitation is close to potential ET, but the effect is not likely to fully mitigate severe drought impacts on streamflow (Sun et al., 2015c). In snow dominated environments, any increments in streamflow also occur earlier in the year (Troendle and King, 1987). In the example from the Boise River noted above, a two week advance in timing accompanied the flow increase, making the added water useless for irrigation water supply and exacerbating snowmelt timing shifts associated with climate change (Cayan et al., 2001).

In contrast to management actions that are intended to augment streamflow, increasing drought stress in some forest ecosystems may warrant management strategies that retain water (and hence reduce streamflow) on the landscape in order to keep trees alive (Grant et al., 2013). Replanting cut forests with species that consume less water is a longer-term solution that may be 
warranted in some cases if it is economically feasible and does not adversely affect other forest management objectives, such as forest productivity, carbon sequestration, wildlife habitat, and water quality (King et al., 2013). For example, Domec et al. (2015) examined risk of hydraulic failure and concluded that intensively managed loblolly pine forests in the southeastern U.S. are much more vulnerable to prolonged droughts than natural forests. Another potential vulnerability in monospecific stands is a lack of inherent resilience compared to multi-species stands and constraints on the ability to select for more drought tolerant species through management actions such as thinning of existing stands. In snow-dominated, coniferous forests of the western U.S., small patch cuts and thinning have been shown to enhance snow accumulation by reducing snow interception and evaporation (Meiman, 1987; Ffolliott et al., 1989); however, these responses are transient as re-growing forests fill-in the openings. Since much of the water supply in the West originates as snowmelt from montane ecosystems, managing subalpine forests to enhance snow accumulation may alleviate the effects of drought on trees in this region.

As with other natural disturbances, droughts are difficult to prepare for because they are unpredictable and onset may be rapid. One consequence of this is that trying to time harvest operations as a response to drought would be difficult. However, there are management options that may be implemented to minimize the impacts of drought on water quality. In more developed areas, an obvious measure is to limit streamwater withdrawals (Webb and Nobilis, 1995; Meier et al., 2003) and wastewater discharge during periods of low-flow, and encourage re-use of treated wastewater to help reduce higher temperature effluent volume entering streams (Kinouchi et al., 2007). In forested areas, efforts should focus on minimizing inputs of sediments and nutrients into the stream. It may be beneficial to plan the timing of management activities so they do not disturb streams during low-flow periods and to avoid vulnerable areas during 
droughts. Since removal and alteration of riparian vegetation can increase stream temperature (Beschta et al., 1987; Dunham et al., 2007; Groom et al., 2011; Isaak et al., 2010; Sun et al., 2004; Swift and Messer, 1971; Swift, 1973; Wooldridge and Stern, 1979), maintaining or increasing shading from solar radiation through riparian buffer conservation and restoration (Burton and Likens, 1973; Swift, 1973; Peterson and Kwak, 1999; Kaushal et al., 2010) may buffer stream temperatures against drought. Other mitigation strategies, such as releases of coldwater from the hypolimnions of deep reservoirs can have a significant cooling effect in downstream reaches (Null et al., 2013) as can discharge of municipal wastewater from underground pipes, which may cool streams in the summer (Bogan et al., 2003).

In summary, a high level of uncertainty in both drought projections and the ability to predict ecohydrological consequences suggests caution in prescribing large-scale management actions to preempt the negative consequences of drought on ecohydrological processes. Instead, we advocate for increased monitoring and science-management partnerships to facilitate strategic implementation of smaller-scale management actions, with adaptive management as a focal point for learning and responding to observed responses and improved understanding (Millar et al. 2014).

\section{Conclusions}

Forest vegetation has a strong influence over the water balance and biogechemical cycling processes that determine stream water quality. Hence, understanding and predicting how drought will impact hydrological processes requires linking vegetation and drought responses across fine (e.g., stomatal regulation) and coarse scales (e.g. community dynamics at watershed scales). Where impacts are large and sudden, and species diversity is less complex (such as widespread 
drought-mediated mountain pine beetle mortality in the western US), assessing short and longterm responses may be possible with existing models (Tague et al., 2013). However, where impacts are smaller scale and longer-term (such as selective mortality in eastern U.S. forests), predicting impacts will be much more difficult and uncertain. If drought frequency and severity increases as expected (Swain and Hayhoe, 2015), understanding the ecohydrological implications will become even more critical. To improve understanding, we have identified several areas of research need:

- Better understanding of species' differences in water use and sensitivity to drought, as well as the thresholds that determine species' physiological capacity to survive drought.

- Better understanding of competitive interactions among species, especially novel species combinations that might result with climate change or other disturbance regimes.

- Better understanding of belowground processes (e.g., root dynamics, hydraulic lift, and soil water access) that interact with drought responses.

- Improved ability to scale from tree-level, plots, and small watersheds to landscape scales in order to understand and predict the ecohydrological consequences of tree-level responses to water balance and streamflow dynamics.

- Better understanding of the impacts of multiple co-occurring stressors on drought responses.

- Better understanding of how water quality is influenced by subsurface flow paths and hydrological connectivity.

- Improved ecohydrological models that couple hydrologic, ecosystem, and plant physiological processes in a dynamic context with appropriate feedbacks. 
- Monitoring the effectiveness of management options to mitigate droughts.

Despite the critical importance of understanding the ecohydrological implications of drought, substantial progress on these research needs will be challenging. For example, experimental studies that simulate drought by manipulating soil moisture through precipitation exclusion are difficult to implement over large spatial scales for long time periods. In addition, the unpredictable nature of drought in space and time makes observational studies post hoc and limits the ability to gain a process-level understanding across the range of conditions and ecosystem types necessary to understand and predict large-scale impacts. At finer spatial scales, difficulty in quantifying and understanding belowground controls in forests has resulted in a "black box", that severely limits the ability of models to predict vegetation controls on streamflow responses to drought accurately. Despite these challenges, new technologies and established and emerging networks may provide new insights. For example, the combination of remote sensing technologies such as the GRACE satellite, the Ameriflux network, NEON, LTER sites, USGS streamflow gauges, U.S. Forest Service Experimental Forests and Ranges, and Forest Inventory Analysis (FIA) plots provide a powerful combination of measurements at a range of spatial scales. 


\section{Acknowledgements}

This project was supported by the USDA Forest Service, Southern Research Station. We thank two anonymous reviewers for helpful comments on a previous version of this manuscript. 


\section{References}

Acuna, V., Datry, T., Marshall, J., Barcelo, D., Dahm, C.N., Ginebreda, A., McGregor, G., Sabater, S., Tockner, K., Palmer, M.A., 2014. Why Should We Care About Temporary Waterways? Science 343, 1080-1081.

Acuña, V., Giorgi, A., Muñoz, I., Sabater, F., Sabater, S., 2007. Meteorological and riparian influences on organic matter dynamics in a forested Mediterranean stream. J. North Amer. Benth. Soc. 26, 54-69.

Adams, H.D., Luce, C.H., Breshears, D.D., Allen, C.D., Weiler, M., Hale, V.C., Smith, A.M.S., Huxman, T.E., 2012. Ecohydrological consequences of drought- and infestationtriggered tree die-off: insights and hypotheses. Ecohydrology 5, 145-159.

Allen, C.D., Macalady, A.K., Chenchouni, H., Bachelet, D., McDowell, N., Vennetier, M., Kitzberger, T., Rigling, A., Breshears, D.D., Hogg, E.H., Gonzalez, P., Fensham, R., Zhang, Z., Castro, J., Demidova, N., Lim, J.-H., Allard, G., Running, S.W., Semerci, A., Cobb, N., 2010. A global overview of drought and heat-induced tree mortality reveals emerging climate change risks for forests. For. Ecol. and Manage. 259, 660-684.

Anderegg, W.R.L., Kane, J.M., Anderegg, L.D.L., 2013. Consequences of widespread tree mortality triggered by drought and temperature stress. Nature Clim. Change 3, 30-36.

Beche, L.A., Connors, P.G., Resh, V.H., Merenlender, A.M., 2009. Resilience of fishes and invertebrates to prolonged drought in two California streams. Ecography 32, 778-788.

Berghuijs, W.R., Woods, R.A., Hrachowitz, M., 2014. A precipitation shift from snow towards rain leads to a decrease in streamflow. Nat Clim. Change 4, 583-586.

Beschta, R.L., Bilby, R.E., Brown, G.W., Holtby, L.B., Hofstra, T.D., 1987. Stream temperature and aquatic habitat: fisheries and forestry interactions. In: Salo, E.O., Cundy, T.W. (Eds.), Streamside Management: Forestry and Fishery Interactions. Institute of Forest Resources, Contribution No. 57. University of Washington, Seattle, Washington, pp. 191-232.

Beschta, R.L., Pyles, M.R., Skaugset, A.E., Surfleet, C.G., 2000. Peakflow responses to forest practices in the western cascades of Oregon, USA. J. Hydrol. 233, 102-120.

Bethlahmy, N., 1974. More Streamflow after a Bark Beetle Epidemic. J. of Hydrol. 23, 185-189.

Binkley, D., Brown, T.C., 1993. Forest Practices as Nonpoint Sources of Pollution in NorthAmerica. Water Resour. Bull. 29, 729-740.

Bjornn, T.C., Reiser, D.W., 1991. Habitat requirements of salmonids in streams. In: Meehan, W.R. (Ed.), Influences of Forest and Rangeland Management on Salmonid Fishes and their Habitats. American Fisheries Special Publication, Bethesda, MD, pp. 83-138.

Bogan, T., Mohseni, O., Stefan, H.G., 2003. Stream temperature-equilibrium temperature relationship. Water Resour. Res. 39.

Boggs, J., Sun, G., Jones, D., McNulty, S.G., 2013. Effect of Soils on Water Quantity and Quality in Piedmont Forested Headwater Watersheds of North Carolina. J. Am. Water Resour. Assoc. 49, 132-150.

Bosch, J.M., Hewlett, J.D., 1982. A Review of Catchment Experiments to Determine the Effect of Vegetation Changes on Water Yield and Evapo-Transpiration. J. Hydrol. 55, 3-23.

Breshears, D.D., Cobb, N.S., Rich, P.M., Price, K.P., Allen, C.D., Balice, R.G., Romme, W.H., Kastens, J.H., Floyd, M.L., Belnap, J., Anderson, J.J., Myers, O.B., Meyer, C.W., 2005. 
Regional vegetation die-off in response to global-change-type drought. P. Natl. Acad. Sci. USA 102, 15144-15148.

Brooks, R.T., 2009. Potential impacts of global climate change on the hydrology and ecology of ephemeral freshwater systems of the forests of the northeastern United States. Climatic Change 95, 469-483.

Brown, A., Zhang, L., McMahon, T., Western, A., Vertessy, R., 2005, A review of paired catchment studies for determining changes in water yield resulting from alterations in vegetation. J. Hydrol. 310, 28-61.

Burt, T.P., Worrall, F., Howden, N.J.K., Anderson, M.G., 2014. Shifts in dischargeconcentration relationships as a small catchment recovers from severe drought. Hydrol. Proc. 29, 498-507.

Burton, T.M., Likens, G.E., 1973. Effect of Strip-Cutting on Stream Temperatures in Hubbard Brook Experimental Forest, New-Hampshire. Bioscience 23, 433-435.

Busch, D.E., Ingraham, N.L., Smith, S.D., 1992. Water Uptake in Woody Riparian Phreatophytes of the Southwestern United States: A Stable Isotope Study. Ecol. Appl. 2, 450-459.

Caissie, D., 2006. The thermal regime of rivers: a review. Freshwater Biol 51, 1389-1406.

Caldwell, P.V., Sun, G., McNulty, S.G., Cohen, E.C., Myers, J.A.M., 2012. Impacts of impervious cover, water withdrawals, and climate change on river flows in the conterminous US. Hydrol. Earth. Sys. Sc. 16, 2839-2857.

Caramujo, M.-J., Mendes, C.R.B., Cartaxana, P., Brotas, V., Boavida, M.-J., 2008. Influence of drought on algal biofilms and meiofaunal assemblages of temperate reservoirs and rivers. Hydrobiologia 598, 77-94.

Cayan, D.R., Kammerdiener, S.A., Dettinger, M.D., Caprio, J.M., Peterson, D.H., 2001. Changes in the onset of spring in the western United States. B. Am. Meteorol. Soc. 82, 399-415.

Choat, B., Jansen, S., Brodribb, T.J., Cochard, H., Delzon, S., Bhaskar, R., Bucci, S.J., Feild, T.S., Gleason, S.M., Hacke, U.G., Jacobsen, A.L., Lens, F., Maherali, H., MartinezVilalta, J., Mayr, S., Mencuccini, M., Mitchell, P.J., Nardini, A., Pittermann, J., Pratt, R.B., Sperry, J.S., Westoby, M., Wright, I.J., Zanne, A.E., 2012. Global convergence in the vulnerability of forests to drought. Nature 491, 752-755.

Clark, J.M., Chapman, P.J., Adamson, J.K., Lane, S.N., 2005. Influence of drought-induced acidification on the mobility of dissolved organic carbon in peat soils. Glob. Change Biol. 11, 791-809.

Clark, J.M., Chapman, P.J., Heathwaite, A.L., Adamson, J.K., 2006. Suppression of dissolved organic carbon by sulfate induced acidification during simulated droughts. Env. Sci. and Tech. 40, 1776-1783.

Clark, M.P., Hendrikx, J., Slater, A.G., Kavetski, D., Anderson, B., Cullen, N.J., Kerr, T., Hreinsson, E.O., Woods, R.A., 2011. Representing spatial variability of snow water equivalent in hydrologic and land-surface models: A review. Wat. Resour. Res. 47, WO7539, doi:10.1029/2011WR010745.

Creutzfeldt, B., Ferre, T., Troch, P., Merz, B., Wziontek, H., Guntner, A., 2012. Total water storage dynamics in response to climate variability and extremes: Inference from longterm terrestrial gravity measurement. J. Geophys. Res.-Atmos. 117, doi:10.1029/2011JD016472. 
Dahm, C.N., Baker, M.A., Moore, D.I., Thibault, J.R., 2003. Coupled biogeochemical and hydrological responses of streams and rivers to drought. Freshwater. Biol. 48, 1219-1231.

De Steven, D., Toner, M.M., 2004. Vegetation of upper coastal plain depression wetlands: Environmental templates and wetland dynamics within a landscape framework. Wetlands 24, 23-42.

Dickson, R., Tomlinson, P., 1996. Oak growth, development and carbon metabolism in response to water stress. Ann. For. Sci. 53, 181-196.

Domec, J.C., King, J.S., Ward, E., Oishi, A.C., Palmroth, S., Radecki, A., Bell, D.M., Miao, G.F., Gavazzi, M., Johnson, D.M., McNulty, S.G., Sun, G., Noormets, A., 2015. Conversion of natural forests to managed forest plantations decreases tree resistance to prolonged droughts. Forest. Ecol. Manage. 355, 58-71.

Douglass, J.E., 1983. The Potential for Water Yield Augmentation from Forest Management in the Eastern-United-States. Water Resour. Bull. 19, 351-358.

Dunham, J.B., Rosenberger, A.E., Luce, C.H., Rieman, B.E., 2007. Influences of wildfire and channel reorganization on spatial and temporal variation in stream temperature and the distribution of fish and amphibians. Ecosystems 10, 335-346.

Ehleringer, J.R., Dawson, T.E., 1992. Water uptake by plants: perspectives from stable isotope composition. Plant, Cell \& Envir. 15, 1073-1082.

Eimers, M.C., Watmough, S.A., Buttle, J.M., Dillon, P.J., 2008. Examination of the potential relationship between droughts, sulphate and dissolved organic carbon at a wetlanddraining stream. Glob. Chan. Biol. 14, 1-11.

Elliott, K.J., Swank, W.T., 1994. Impacts of Drought on Tree Mortality and Growth in a Mixed Hardwood Forest. J. Veg. Sci. 5, 229-236.

Emanuel, R.E., Epstein, H.E., McGlynn, B.L., Welsch, D.L., Muth, D.J., D'Odorico, P., 2010. Spatial and temporal controls on watershed ecohydrology in the northern Rocky Mountains. Water Resour. Res. 46, W11553. doi:10.1029/2009WR008890.

Everard, M., 1996. The importance of periodic droughts for maintaining diversity in the freshwater environment. Freshwater Forum 7, 33-50.

Fan, Y., Li, H., Miguez-Macho, G., 2013. Global Patterns of Groundwater Table Depth. Science 339, 940-943.

Fan, Y., Miguez-Macho, G., 2011. A simple hydrologic framework for simulating wetlands in climate and earth system models. Clim. Dynam. 37, 253-278.

Ffolliott, P.F., Gottfried, G.J., Baker, M.B., 1989. Water yield from forest snowpack management: Research findings in Arizona and New Mexico. Water Resour. Res. 25, 1999-2007.

Fisher, S.G., Grimm, N.B., Martí, E., Holmes, R.M., Jones, J.B., 1998. Material spiraling in river corridors: a telescoping ecosystem model. Ecosystems 1, 19-34.

Ford, C.R., Hubbard, R.M., Vose, J.M., 2011a. Quantifying structural and physiological controls on variation in canopy transpiration among planted pine and hardwood species in the southern Appalachians. Ecohydrology 4, 183-195.

Ford, C.R., Laseter, S.H., Swank, W.T., Vose, J.M., 2011b. Can forest management be used to sustain water-based ecosystem services in the face of climate change? Ecol. Appl. 21, 2049-2067.

Frank, D.A., Inouye, R.S., 1994. Temporal Variation in Actual Evapotranspiration of Terrestrial Ecosystems - Patterns and Ecological Implications. J. Biogeogr. 21, 401-411. 
Goode, J.R., Luce, C.H., Buffington, J.M., 2012. Enhanced sediment delivery in a changing climate in semi-arid mountain basins: Implications for water resource management and aquatic habitat in the northern Rocky Mountains. Geomorphology 139, 1-15.

Govind, A., Chen, J.M., Margolis, H., Ju, W.M., Sonnentag, O., Giasson, M.A., 2009. A spatially explicit hydro-ecological modeling framework (BEPS-TerrainLab V2.0): Model description and test in a boreal ecosystem in Eastern North America. J. Hydrol. 367, 200216.

Grant, G.E., Tague, C.L., Allen, C.D., 2013. Watering the forest for the trees: an emerging priority for managing water in forest landscapes. Front. Ecol. Environ. 11, 314-321.

Groom, J.D., Dent, L., Madsen, L.J., 2011. Stream temperature change detection for state and private forests in the Oregon Coast Range. Water Resour. Res. 47.

Guardiola-Claramonte, M., Troch, P.A., Breshears, D.D., Huxman, T.E., Switanek, M.B., Durcik, M., Cobb, N.S., 2011. Decreased streamflow in semi-arid basins following drought-induced tree die-off: a counter-intuitive and indirect climate impact on hydrology. J. Hydrol. 406, 225-233.

Hadley, J.L., Kuzeja, P.S., Daley, M.J., Phillips, N.G., Mulcahy, T., Singh, S., 2008. Water use and carbon exchange of red oak- and eastern hemlock-dominated forests in the northeastern USA: implications for ecosystem-level effects of hemlock woolly adelgid. Tree Phys. 28, 615-627.

Hakala, J.P., Hartman, K.J., 2004. Drought effect on stream morphology and brook trout (Salvelinus fontinalis) populations in forested headwater streams. Hydrobiologia 515, 203-213.

Hanson, P.J., Amthor, J.S., Wullschleger, S.D., Wilson, K.B., Grant, R.F., Hartley, A., Hui, D., Hunt, E.R., Johnson, D.W., Kimball, J.S., King, A.W., Luo, Y., McNulty, S.G., Sun, G., Thornton, P.E., Wang, S., Williams, M., Baldocchi, D.D., Cushman, R.M., 2004. Oak forest carbon and water simulations: Model intercomparisons and evaluations against independent data. Ecol. Monogr. 74, 443-489.

Hendrick, R.L., Pregitzer, K.S., 1996. Temporal and depth-related patterns of fine root dynamics in northern hardwood forests. J. Ecol. 48, 167-176.

Hester, E.T., Doyle, M.W., 2011. Human Impacts to River Temperature and Their Effects on Biological Processes: A Quantitative Synthesis. J. Am. Water. Resour. Assoc. 47, 571587.

Hockey, J.B., I. F. Owens, and N. J. Tapper, 1982. Empirical and theoretical models to isolate the effect of discharge on summer water temperatures in the Hurunui River. J. of Hydrol. (New Zealand) 21, 1-12.

Hokanson, K.E.F., Kleiner, C.F., Thorslund, T.W., 1977. Effects of Constant Temperatures and Diel Temperature-Fluctuations on Specific Growth and Mortality-Rates and Yield of Juvenile Rainbow-Trout, Salmo-Gairdneri. J. Fish. Res. Board. Can. 34, 639-648.

Hwang, T., Band, L., Hales, T.C., 2009. Ecosystem processes at the watershed scale: Extending optimality theory from plot to catchment. Water Resour. Res. 45, W11425, doi:10.1029/2009WR00775.

Isaak, D.J., Luce, C.H., Rieman, B.E., Nagel, D.E., Peterson, E.E., Horan, D.L., Parkes, S., Chandler, G.L., 2010. Effects of climate change and wildfire on stream temperatures and salmonid thermal habitat in a mountain river network. Ecol. Appl. 20, 1350-1371. 
Isaak, D.J., Wollrab, S., Horan, D., Chandler, G., 2012. Climate change effects on stream and river temperatures across the northwest US from 1980-2009 and implications for salmonid fishes. Climatic Change 113, 499-524.

Jackson, R.B., Jobbagy, E.G., Nosetto, M.D., 2009. Ecohydrology in a human-dominated landscape. Ecohydrology 2, 383-389.

Jaeger, K.L., Olden, J.D., 2012. Electrical Resistance Sensor Arrays as a Means to Quantify Longitudinal Connectivity of Rivers. River Res. Appl. 28, 1843-1852.

Jones, J.A., Creed, I.F., Hatcher, K.L., Warren, R.J., Adams, M.B., Benson, M.H., Boose, E., Brown, W.A., Campbell, J.L., Covich, A., Clow, D.W., Dahm, C.N., Elder, K., Ford, C.R., Grimm, N.B., Henshaw, D.L., Larson, K.L., Miles, E.S., Miles, K.M., Sebestyen, S.D., Spargo, A.T., Stone, A.B., Vose, J.M., Williams, M.W., 2012. Ecosystem Processes and Human Influences Regulate Streamflow Response to Climate Change at Long-Term Ecological Research Sites. Bioscience 62, 390-404.

Jones, J.A., Perkins, R.M., 2010. Extreme flood sensitivity to snow and forest harvest, western Cascades, Oregon, United States. Water Resour. Res. 46, W12512, doi:10.1029/2009WR008632.

Joslin, J.D., Gaudinski, J.B., Torn, M.S., Riley, W.J., Hanson, P.J., 2007. Fine-root turnover patterns and their relationship to root diameter and soil depth in a C-14-labeled hardwood forest.. New. Phytol. 173, 445-445.

Kaller, M.D., Hartman, K.J., 2004. Evidence of a threshold level of fine sediment accumulation for altering benthic macroinvertebrate communities. Hydrobiologia 518, 95-104.

Kattelmann, R.C., Berg, N.H., Rector, J., 1983. The potential for increasing streamflow from Sierra Nevada watersheds. J. Am. Water Resour. Assoc. 19, 395-402.

Katz, D.L., Moore, M.R., 2011. Dividing the waters: An empirical analysis of interstate compact allocation of transboundary rivers. Water Resour. Res. 47, doi:10.1029/2010WR009736.

Kaushal, S.S., Likens, G.E., Jaworski, N.A., Pace, M.L., Sides, A.M., Seekell, D., Belt, K.T., Secor, D.H., Wingate, R.L., 2010. Rising stream and river temperatures in the United States. Front. Ecol. Environ. 8, 461-466.

Kemp, P., Sear, D., Collins, A., Naden, P., Jones, I., 2011. The impacts of fine sediment on riverine fish. Hydrol. Process. 25, 1800-1821.

King, J.S., Ceulemans, R., Albaugh, J.M., Dillen, S.Y., Domec, J.C., Fichot, R., Fischer, M., Leggett, Z., Sucre, E., Trnka, M., Zenone, T., 2013. The Challenge of Lignocellulosic Bioenergy in a Water-Limited World. Bioscience 63, 102-117.

Kinouchi, T., Yagi, H., Miyamoto, M., 2007. Increase in stream temperature related to anthropogenic heat input from urban wastewater. J. Hydrol. 335, 78-88.

Klos, R.J., Wang, G.G., Bauerle, W.L., Rieck, J.R., 2009. Drought impact on forest growth and mortality in the southeast USA: an analysis using Forest Health and Monitoring data. Ecol. Appl. 19, 699-708.

Lake, P.S., 2003. Ecological effects of perturbation by drought in flowing waters. Freshwater Biol. 48, 1161-1172.

Law, B.E., Williams, M., Anthoni, P.M., Baldocchi, D.D., Unsworth, M.H., 2000. Measuring and modelling seasonal variation of carbon dioxide and water vapour exchange of a Pinus ponderosa forest subject to soil water deficit. Glob. Change Biol. 6, 613-630. 
Loheide, S.P., Butler, J.J., Gorelick, S.M., 2005. Estimation of groundwater consumption by phreatophytes using diurnal water table fluctuations: A saturated-unsaturated flow assessment. Water Resour. Res. 41, WO7030.doi:10.1029/2005WR003942.

Lowe, W.H., Likens, G.E., 2005. Moving headwater streams to the head of the class. Bioscience 55, 196-197.

Lowry, C.S., Loheide, S.P., 2010. Groundwater-dependent vegetation: Quantifying the groundwater subsidy. Water Resour. Res. 46, WO602.doi:10.1029/2009WR008874.

Lu, J.B., Sun, G., McNulty, S.G., Comerford, N.B., 2009. Sensitivity of Pine Flatwoods Hydrology to Climate Change and Forest Management in Florida, USA. Wetlands 29, 826-836.

Lu, N., Sun, G., Feng, X.M., Fu, B.J., 2013. Water yield responses to climate change and variability across the North-South Transect of Eastern China (NSTEC). J. Hydrol. 481, 96-105.

Lubczynski, M.W., Gurwin, J., 2005. Integration of various data sources for transient groundwater modeling with spatio-temporally variable fluxes - Sardon study case, Spain. J. Hydrol. 306, 71-96.

Luce, C.H., Vose, J.M., Campbell, J.. Millar, C., Kormos, P., Woods, R. 2016. Contributing factors for drought in forest ecosystems and future climates. For Ecol Manag **:**.

Luce, C. H., Lopez-Burgos, V., Holden, Z., 2014, Sensitivity of snowpack storage to precipitation and temperature using spatial and temporal analog models, Water Resour. Res. 50, 9447-9462, 10.1002/2013WR014844.

Luce, C., Morgan, P., Dwire, K., Isaak, D., Holden, Z., Rieman, B. 2012. Climate Change, Forests, Fire, Water, and Fish: Building resilient landscapes, streams, and managers, General Technical Report RMRS-GTR-290. USDA Forest Service, Fort Collins, Co.

Luce, C.H., Holden, Z.A., 2009. Declining annual streamflow distributions in the Pacific Northwest United States, 1948-2006. Geophys. Res. Lett. 36, LI6401, doi:10.1029/2009GL039407.

Luce, C.H., Tarboton, D.G., Cooley, R.R., 1998. The influence of the spatial distribution of snow on basin-averaged snowmelt. Hydrol. Process. 12, 1671-1683.

Lundquist, J.D., Dickerson-Lange, S.E., Lutz, J.A., Cristea, N.C., 2013. Lower forest density enhances snow retention in regions with warmer winters: A global framework developed from plot-scale observations and modeling. Water Resour. Res. 49, 6356-6370.

Luo, Y.Q., Gerten, D., Le Maire, G., Parton, W.J., Weng, E.S., Zhou, X.H., Keough, C., Beier, C., Ciais, P., Cramer, W., Dukes, J.S., Emmett, B., Hanson, P.J., Knapp, A., Linder, S., Nepstad, D., Rustad, L., 2008. Modeled interactive effects of precipitation, temperature, and [CO2] on ecosystem carbon and water dynamics in different climatic zones. Glob. Change Biol. 14, 1986-1999.

Lutz, B.D., Mulholland, P.J., Bernhardt, E.S., 2012. Long-term data reveal patterns and controls on stream water chemistry in a forested stream: Walker Branch, Tennessee. Ecol. Mono. 82, 367-387.

Lytle, D.A., Poff, N.L., 2004. Adaptation to natural flow regimes. Trends in Ecol. \& Evol. 19, 94-100.

Ma, Z.M., Kang, S.Z., Zhang, L., Tong, L., Su, X.L., 2008. Analysis of impacts of climate variability and human activity on streamflow for a river basin in arid region of northwest China. J. Hydrol. 352, 239-249. 
Maxwell, R.M., Kollet, S.J., 2008. Interdependence of groundwater dynamics and land-energy feedbacks under climate change. Nat. Geosci. 1, 665-669.

McDonough, C.J., Wenner, C.A., Roumillat, W.A., 2011. Age, Growth, and Reproduction of Sheepsheads in South Carolina. Mar. Coast. Fish. 3, 366-382.

McDowell, N., Pockman, W.T., Allen, C.D., Breshears, D.D., Cobb, N., Kolb, T., Plaut, J., Sperry, J., West, A., Williams, D.G., Yepez, E.A., 2008. Mechanisms of plant survival and mortality during drought: why do some plants survive while others succumb to drought? New Phytol. 178, 719-739.

McLaughlin, D.L., Kaplan, D.A., Cohen, M.J., 2013. Managing Forests for Increased Regional Water Yield in the Southeastern U.S. Coastal Plain. J. Am. Water Res. Assoc. 49, 953965.

Meier, W., Bonjour, C., Wuest, A., Reichert, P., 2003. Modeling the effect of water diversion on the temperature of mountain streams. J. Environ. Eng.-Asce 129, 755-764.

Meiman, J.R., 1987. Influence of forests on snowpack accumulation. In: (Eds.), . In: Troendle, C.A., Kaufmann, M.R., Hamre, R.H., Winokur, R.P. (Eds.), Management of Subalpine Forests: Building on 50-years of Research, USDA Forest Service Gen. Tech. Rept. RM149, pp. 61-67.

Millar, C.I., Swanston, C.W., Peterson, D.L. 2014. Adapting to climate change. In: Peterson, D.L., J.M. Vose, and T. Patel-Weynand (eds.), Climate Change and United States Forests. Advances in Global Change Research 57, Springer, New York. pp. 183-222.

Miller, G.R., Chen, X., Rubin, Y., Ma, S., Baldocchi, D.D., 2010. Groundwater uptake by woody vegetation in a semiarid oak savanna. Water Resour. Res. 46, W10503, doi:10.1029/2009WR008902.

Milly, P.C.D., Dunne, K.A., 2002. Macroscale water fluxes - 2. Water and energy supply control of their interannual variability. Water Resour. Res. 38, doi:10.1029/2001WR00760.

Mohseni, O., Stefan, H.G., Eaton, J.G., 2003. Global warming and potential changes in fish habitat in US streams. Climatic Change 59, 389-409.

Mote, P.W., 2006. Climate-driven variability and trends in mountain snowpack in western North America. J. Climate 19, 6209-6220.

Nichols, W.D., 1994. Groundwater Discharge by Phreatophyte Shrubs in the Great-Basin as Related to Depth to Groundwater. Water. Resour. Res. 30, 3265-3274.

Nilsen, E.T., Sharifi, M.R., Rundel, P.W., 1984. Comparative Water Relations of Phreatophytes in the Sonoran Desert of California. Ecology 65, 767-778.

Null, S.E., Ligare, S.T., Viers, J.H., 2013. A Method to Consider Whether Dams Mitigate Climate Change Effects on Stream Temperatures. J. Am. Water Resour. Assoc. 49, 14561472.

Ohnuki, Y., Kimhean, C., Shinomiya, Y., Toriyama, J., 2008. Distribution and characteristics of soil thickness and effects upon water storage in forested areas of Cambodia. Hydrol. Process. 22, 1272-1280.

Orellana, F., Verma, P., Loheide, S.P., Daly, E., 2012. Monitoring and modeling watervegetation interactions in groundwater-dependent ecosystems. Rev. of Geophys. 50, RG3003, doi:10.1029/2011RG000383.

Peterson, D.P., Wenger, S.J., Rieman, B.E., Isaak, D.J., 2013. Linking Climate Change and Fish Conservation Efforts Using Spatially Explicit Decision Support Tools. Fisheries 38, 112127. 
Peterson, J.T., Kwak, T.J., 1999. Modeling the effects of land use and climate change on riverine smallmouth bass. Ecol. Appl. 9, 1391-1404.

Porcal, P., -F., K.J., Molot, L.A., Dillon, P.J., 2009. Humic substances-part 7: the biogeochemistry of dissolved organic carbon and its interactions with climate change. Env. Sci. Poll. Res. 16, 714-726.

Potter, N.J., Chiew, F.H.S., 2011. An investigation into changes in climate characteristics causing the recent very low runoff in the southern Murray-Darling Basin using rainfallrunoff models. Water Resour. Res. 47, doi:10.1029/2010WR010333.

Powell, T.L., Galbraith, D.R., Christoffersen, B.O., Harper, A., Imbuzeiro, H.M.A., Rowland, L., Almeida, S., Brando, P.M., da Costa, A.C.L., Costa, M.H., Levine, N.M., Malhi, Y., Saleska, S.R., Sotta, E., Williams, M., Meir, P., Moorcroft, P.R., 2013. Confronting model predictions of carbon fluxes with measurements of Amazon forests subjected to experimental drought. New Phytol. 200, 350-364.

Price, K., 2011. Effects of watershed topography, soils, land use, and climate on baseflow hydrology in humid regions: A review. Prog. Phys. Geog. 35, 465-492.

Raymond, P.A., Saiers, J.E., 2010. Event controlled DOC export from forested watersheds. Biogeochemistry 100, 197-209.

Rieman, B., Lee, D., Burns, D., Gresswell, R., Young, M., Stowell, R., Rinne, J., Howell, P., 2003. Status of native fishes in the western United States and issues for fire and fuels management. For. Ecol. Manage. 178, 197-211.

Robson, B.J., Chester, E.T., Austin, C.M., 2011. Why life history information matters: drought refuges and macroinvertebrate persistence in non-perennial streams subject to a drier climate. Mar. Freshwater Res. 62, 801-810.

Rodriguez-Iturbe, I., 2000. Ecohydrology: A hydrologic perspective of climate-soil-vegetation dynamics. Water Resour. Res. 36, 3-9.

Sanford, W.E., Selnick, D.L., 2013. Estimation of Evapotranspiration Across the Conterminous United States Using a Regression With Climate and Land-Cover Data. J. Am. Water Resour. Assoc. 49, 217-230.

Schindler, D.W., Curtis, P.J., Bayley, S.E., Parker, B.R., Beaty, K.G., Stainton, M.P., 1997. Climate-induced changes in the dissolved organic carbon budgets of boreal lakes. Biogeochemistry 36, 9-28.

Schlesinger, W.H., Jasechko, S., 2014. Transpiration in the global water cycle. Agr. Forest Meteorol. 189, 115-117.

Scott, M.J., Jones, M.N., Woof, C., Tipping, E., 1998. Concentrations and fluxes of dissolved organic carbon in drainage water from an upland peat system. Environ. Int. 24, 537-546.

Smith, H.G., Sheridan, G.J., Lane, P.N.J., Nyman, P., Haydon, S., 2011. Wildfire effects on water quality in forest catchments: A review with implications for water supply. J. Hydrol. 396, 170-192.

Smith, S.D., Devitt, D.A., Sala, A., Cleverly, J.R., Busch, D.E., 1998. Water relations of riparian plants from warm desert regions. Wetlands 18, 687-696.

Soylu, M.E., Kucharik, C.J., Loheide, S.P., 2014. Influence of groundwater on plant water use and productivity: Development of an integrated ecosystem - Variably saturated soil water flow model. Agr. Forest Meteorol. 189, 198-210.

Spencer, C.N., Gabel, K.O., Hauer, F.R., 2003. Wildfire effects on stream food webs and nutrient dynamics in Glacier National Park, USA. For. Ecol. Manage. 178, 141-153. 
Stednick, J.D., 1996. Monitoring the effects of timber harvest on annual water yield. J. Hydrol. 176, 79-95.

Stott, R.E., Burt, T.P., 1997. Potassium chemistry of a small upland stream following a major drought. Hydrol. Process. 11, 189-201.

Sun, S.-L., G. Sun, P. Caldwell, S. McNulty, E. Cohen, J.-F. Xiao, and Y. Zhang, 2015a, Drought Impacts on Ecosystem Functions of the U.S. National Forests and Grasslands: Part I. Evaluation of a Water and Carbon Balance Model. For. Ecol. Manage. 353,260268.

Sun, S.-L., G. Sun, P. Caldwell, S. McNulty, E. Cohen, J.-F. Xiao, and Y. Zhang, 2015b, Drought Impacts on Ecosystem Functions of the U.S. National Forests and Grasslands: Part II Model Results and Management Implications. For. Ecol. Manage. 353,269-279.

Sun, G., Peter V. Caldwell, and Steven G. McNulty. 2015c. Modeling the potential role of forest thinning in maintaining water supplies under a changing climate across the Conterminous United States. Hydrol. Proc. doi: 10.1002/hyp.10469 .

Sun, G., Caldwell, P., Noormets, A., McNulty, S.G., Cohen, E., Myers, J.M., Domec, J.C., Treasure, E., Mu, Q.Z., Xiao, J.F., John, R., Chen, J.Q., 2011. Upscaling key ecosystem functions across the conterminous United States by a water-centric ecosystem model. J Geophys. Res. 116, G00J05, doi:10.1029/2010JG001573.

Sun, G., Noormets, A., Gavazzi, M.J., McNulty, S.G., Chen, J., Domec, J.C., King, J.S., Amatya, D.M., Skaggs, R.W., 2010. Energy and water balance of two contrasting loblolly pine plantations on the lower coastal plain of North Carolina, USA. For. Ecol Manage. 259, 1299-1310.

Sun, G., Riedel, M., Jackson, R., Kolka, R., Amatya, D., Shepard, J., 2004. Influences of management of Southern forests on water quantity and quality. In: Rauscher, H.M., Johnsen, K. (Eds.), Southern Forest Sciences: Past, Current, and Future. Gen. Tech. Rep/ SRS-75.

Swain, S., Hayhoe, K., 2015. CMIP5 projected changes in spring and summer drought and wet conditions over North America. Clim. Dynam. 44, 2737-2750.

Swank, W.T., Knoepp, J.D., Vose, J.M., Laseter, S.N., Webster, J.R., 2014. Response and recovery of water yield and timing, stream sediment, abiotic parameters, and stream chemistry following logging. Oxford Press, 35-56.

Swift, L.W., Jr., 1973. Lower water temperatures within a streamside buffer strip. In. U.S. Department of Agriculture, Forest Service, Southeastern Forest Experiment Station, Asheville, NC, p. 7.

Swift, L.W., Messer, J.B., 1971. Forest Cuttings Raise Temperatures of Small Streams in Southern Appalachians. J. Soil Water Conserv. 26, 111-116.

Swistock, B.R., DeWalle, D.R., Sharpe, W.E., 1989. Sources of acidic stormflow in an Appalachian headwater stream. Water Res. Resour. 25, 2139-2147.

Tague, C., Grant, G.E., 2009. Groundwater dynamics mediate low-flow response to global warming in snow-dominated alpine regions. Water Resour. Res. 45, doi:10.1029/2008WR007179. Tague, C.L., Choate, J.S., Grant, G., 2013. Parameterizing sub-surface drainage with geology to improve modeling streamflow responses to climate in data limited environments. Hydrol. Earth Syst. Sc. 17, 341-354. 
Taylor, I.H., Burke, E., McColl, L., Falloon, P.D., Harris, G.R., McNeall, D., 2013. The impact of climate mitigation on projections of future drought. Hydrol. Earth Syst. Sc. 17, 23392358.

Thorburn, P., Walker, G., Hatton, T., 1992. Are river red gums taking water from soil, groundwater or streams? . In, National Conference on Vegetation and Water Management, Adelaide, pp. 37-42.

Troendle, C., King, R., 1987, The effect of partial and clearcutting on streamflow at Deadhorse Creek, Colorado, J. Hydrol. 90, 145-157.

Vose, J.M., Sun, G., Ford, C.R., Bredemeier, M., Otsuki, K., Wei, X., Zhang, Z., Zhang, L., 2011. Forest ecohydrological research in the 21st century: what are the critical needs? Ecohydrology 4, 146-158.

Vose, J.M., Swank, W.T., 1994. Effects of Long-Term Drought on the Hydrology and Growth of a White-Pine Plantation in the Southern Appalachians. Forest Ecol. Manage. 64, 25-39.

Vose, J.M. C. F. Miniat, C. H. Luce, H. Asbjornsen, P.V. Caldwell, J. L. Campbell, G. E. Grant, D. J. Isaak, S. P. Loheide, and G. Sun. 2016. Ecohydrological implications of drought. pp. 231-251 In Vose, J.M., J.S. Clark, C.H. Luce, and T. Patel-Weynand (editors), Drought Impacts on U.S. Forests and Rangelands: A Comprehensive Science Synthesis. WO-GTR-93b. Washington, DC: US Department of Agriculture, Forest Service, Washington Office. 289 p.

Webb, B.W., 1996. Trends in stream and river temperature. Hydrol. Process. 10, 205-226.

Webb, B.W., Clack, P.D., Walling, D.E., 2003. Water-air temperature relationships in a Devon river system and the role of flow. Hydrol. Process. 17, 3069-3084.

Webb, B.W., Nobilis, F., 1995. Long-Term Water Temperature Trends in Austrian Rivers. Hydrolog. Sci. J 40, 83-96.

Weed, A.S., Ayres, M.P., Hicke, J.A., 2013. Consequences of climate change for biotic disturbances in North American forests. Ecol. Monogr. 83, 441-470.

Westerling, A.L., Hidalgo, H.G., Cayan, D.R., Swetnam, T.W., 2006. Warming and earlier spring increase western US forest wildfire activity. Science 313, 940-943.

Wilcox, B.P., Thurow, T.L., 2006. Emerging issues in rangeland ecohydrology: Vegetation change and the water cycle. Rangeland Ecol. Manage. 59, 220-224.

Wolock, D.M., McCabe, G.J., 1999. Explaining spatial variability in mean annual runoff in the conterminous United States. Climate Res. 11, 149-159.

Wood, P.J., Armitage, P.D., 1997. Biological effects of fine sediment in the lotic environment. Environ. Manage. 21, 203-217.

Wood, P.J., Armitage, P.D., 1999. Sediment deposition in a small lowland stream - Management implications. Regulated Rivers: Res. \& Manage. 15, 199-210.

Wooldridge, D.D., Stern, D., 1979. Relationships of silvicultural activities and thermally sensitive forest streams. In. University of Washington, College of Forest Resources, Seattle, Washington, p. 90.

Worrall, F., Burt, T.P., 2008. The effect of severe drought on the dissolved organic carbon (DOC) concentration and flux from British rivers. J. Hydrol. 361, 262-274.

Wullschleger, S.D., Hanson, P.J., Todd, D.E., 2001. Transpiration from a multi-species deciduous forest as estimated by xylem sap flow techniques. Forest Ecol. Manage. 143, 205-213. 
Wurzburger, N., Miniat, C.F., 2014. Drought enhances symbiotic dinitrogen fixation and competitive ability of a temperate forest tree. Oecologia 174, 1117-1126.

Zhang, L., Dawes, W.R., Walker, G.R., 2001. Response of mean annual evapotranspiration to vegetation changes at catchment scale. Water Resour. Res. 37, 701-708. 


\section{Figure Titles}

Fig. 1. Conceptualization of major water pools and fluxes in a forested catchment. The catchment water balance can be viewed as partitioning of precipitation into evapotranspirative and drainage fluxes.

Fig. 2. Spatial distribution of annual forest water yield response (\% reduction in water yield) to a $10 \%$ decrease in precipitation across the conterminous U.S. Darker shades represent a greater percent reduction relative to lighter shades. Simulation results at the USGS HUC-8 scale are presented at $1 \mathrm{~km}$ resolution by a mask of forest land cover (from Sun et al., 2015).

Fig. 3. Mean growing season daily water use across species sampled in the Coweeta Basin. Reproduced from Ford et al., (2011b).

Fig. 4. Across a regional gradient from southern Appalachian forests (top) to Coastal Plain forests (bottom), percent loss of hydraulic conductivity (PLC) for co-occurring spp. varied by xylem type; ring-porous trees had $>50 \%$ dysfunction under the same soil water potentials as diffuse porous \& tracheid-type spp. Evidence suggests that mortality occurs when plants experience $>80 \%$. Bars represent the mean PLC across five individuals from each species sampled three times throughout the growing season (May, August, October 2010). Bars are standard error. PLC was determined using a flowmeter (Xyl'em, Bronkhorst, FR) and the following equation: $[(\mathrm{ks}(\max )-\mathrm{ks}(\mathrm{P})) / \mathrm{ks}(\max )]$, where $\mathrm{ksP}$ is the hydraulic conductivity at the time of sampling from the field, and $\mathrm{ks}(\max )$ is the conductivity determined after fully saturating the sample under vacuum for 24 hrs or with high positive pressure. Data from CF Miniat and JM Vose, unpublished. Species codes along the x-axis are: ACRU: red maple; LITU=tulip poplar; 
LIST=sweetgum; NYSY= black gum; QUAL, QUCO= white and scarlet oak; CELO= sugarberry; ULSP= American elm; PIRI, PITA= pitch and loblolly pine 


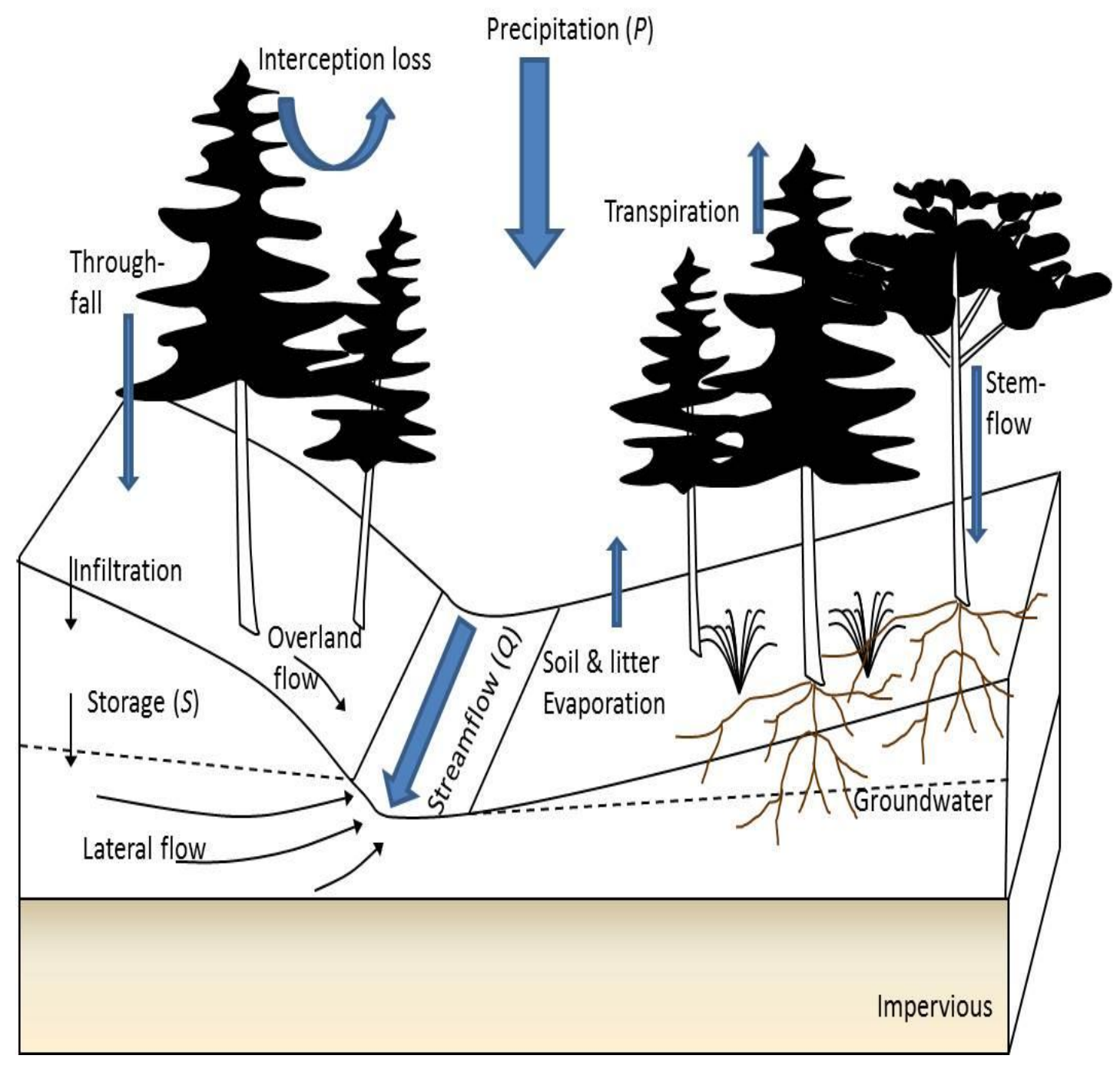

Fig. 1. 


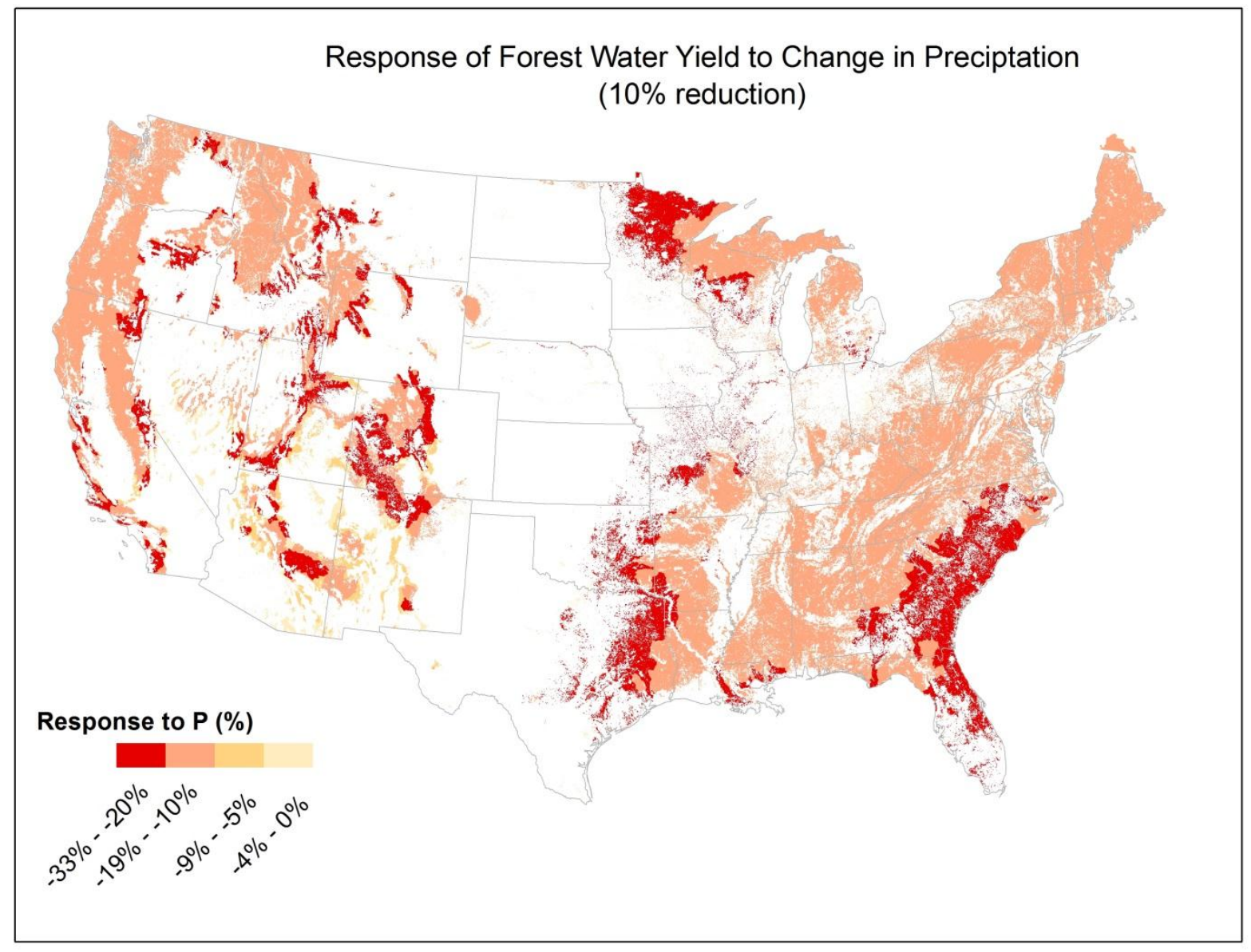

Fig. 2. 


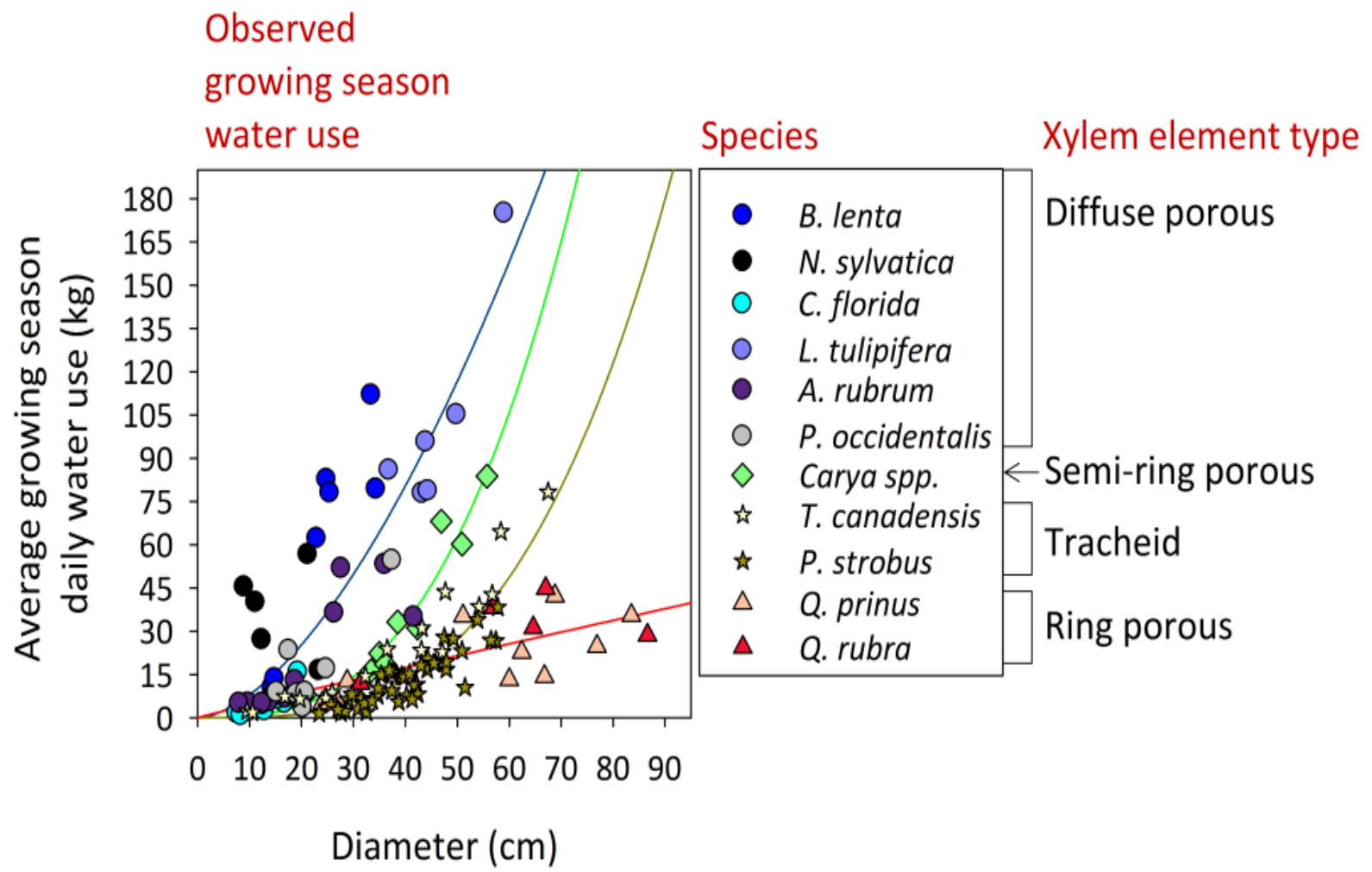

Fig. 3. 

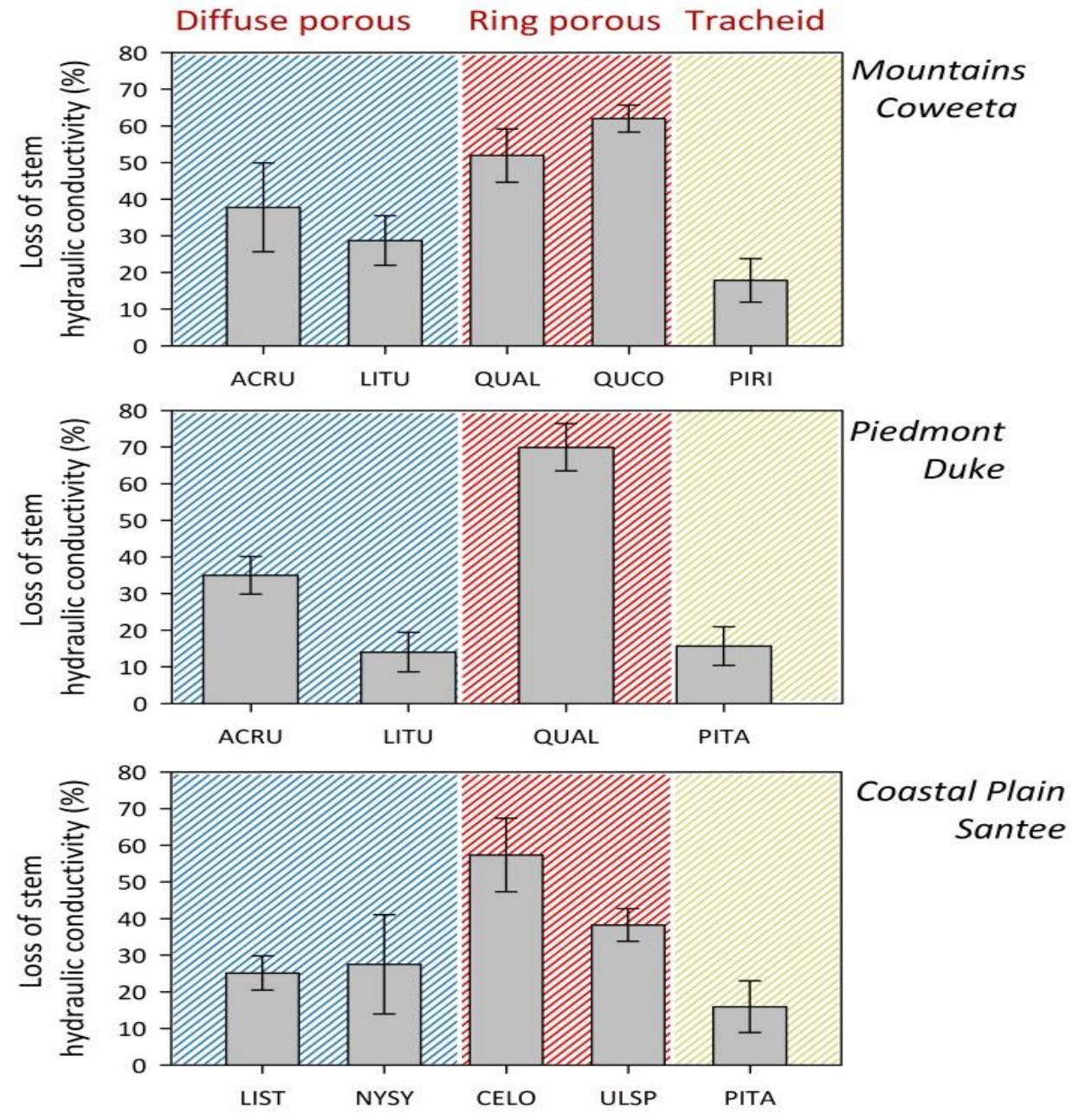

Fig. 4. 